\begin{tabular}{l|l|l|l|l}
\hline Volume 1 & Issue 1 & April (2020) & DOI: 10.47540/ijsei.v1i1.5 & Page: $16-21$ \\
\hline
\end{tabular}

\title{
Livelihood Strategy of Scavengers in Kendari City
}

\author{
Rati Anggriawati ${ }^{1}$, Syaifudin S. Kasim ${ }^{2}$, Dewi Anggraini ${ }^{3}$ \\ ${ }^{1,2,3}$ Department of Sociology Halu Oleo University, Indonesia
}

Corresponding Author: Rati Anggriawati; Email: ratyanggriawaty@gmail.com

A R T I C L E I N F O
Keywords: Livelihood Strategies;
Needs; Family Scavengers.
Received $\quad: 21$ January 2020
Revised $\quad: 25$ February 2020
Accepted $\quad: 27$ March, 2020
\begin{abstract}
A B S T R A C T
The purpose of this study was to determine the various barriers faced by scavengers in satisfying the needs of family life and livelihood strategies of scavengers in the Final Waste Disposal Site (TPAS) in Kendari City. The research approach used is a qualitative descriptive approach. Informants in this study include the Head of Rukun Tetangga, Kendari City Sanitation Department staffers and 11 scavengers. The results of this study indicate that various barriers faced by scavengers in fulfilling the needs of family life in TPAS in Kendari City are scavengers who do not have their production assets, the difficulty of getting credit under the pattern of livelihoods, lack of alternative livelihoods. The strategies undertaken in fulfilling the life needs of scavenger families in TPAS in Kendari City include active strategies, passive strategies, and network strategies. Active strategy, when fulfilling the needs of life by a person or family by maximizing all the resources and potential possessed by their family. The passive strategy is a survival strategy that is done by minimizing family expenses. While the network strategy is a strategy carried out by utilizing social networks.
\end{abstract}

\section{INTRODUCTION}

One of the poor conditions of the State of Indonesia is the high level of rural population density in cities called urbanization. Urbanization in developing countries can increase the population of cities to become very large, but with very low quality (Wurdjinem, 2001). There is one thing that convinces them to be able to live in the city is their belief in their abilities.

The rapid rate of population growth in the development of technology and various means of life in urban areas is not in line with the development of social welfare. The concept of strategy in the social sciences mainly deals with the way how people deal with difficult circumstances with all its challenges. Although the response they can take to new forms depends on their history and geographical location, in reality, people can find ways to face challenges to survive. This kind of thing shows the existence of peripheral communities such as scavengers.

The level of awareness of the surrounding community with the scavenger community is well established not only seen in terms of interaction, but it is also marked by the assistance of the surrounding community to the scavenger community. The mechanism for fulfilling the life needs of scavenger families in the TPAS location is based on food needs, clothing needs, and board needs. Another method used by these scavengers is through the relationship they have built with the stall owner. The stalls are used as a place to ask for help. Scavengers assume that waste is a field that can support their families.

Scavengers are one example of informal sector activities in urban areas. Scavengers collect used goods because there is demand from industries to recycle used materials. The presence is not profitable, due to lack of income, business losses, and lack of freedom as well as more waste collectors because they are tempted by the socialization of neighbors which promises ease in finding work with large income in the city. The form of cooperation between scavengers and shanties is very good. This happens because there are trust and reciprocity and the information network that they have is their social capital to survive in the city (Gunawan, 2012).

Based on the results of Abidin's research (2007), proving that the existence of scavengers in 
the Benowo Region, in particular, raises a very significant role for the community and the surrounding environment. Meanwhile, according to Birkbeck (in Twikromo, 1999) regarding scavengers in Cali, Colombia that the proportion of potential recycled goods for sale is collected by the scavengers in their ways and part of the proceeds is for large factories.

Work as scavengers may often be considered unfit for some people, but without us knowing that it is one of the jobs that they can pursue to survive. Especially to provide for many families with the guidance of their children who indeed continue their education so that one day they can also be seen by the community.

In Kendari City itself, there are already many people who do professions as scavengers, this can be seen from the existence of scavengers who dig up trash bins on the side of the road that has trash bins, moreover at the Final Garbage Disposal Site (TPAS), wherein this place besides being the center of scavenger work, they also make a place to live in this area. Meeting all the needs of family life is the responsibility of a family head and meeting all kinds of family needs is certainly not easy, as is the case for a scavenger.

Based on the description above, the objectives in this study are various obstacles encountered and strategies for meeting the needs of family life in the Final Waste Disposal Site (TPAS) in Puuwatu Village, Puuwatu District, Kendari City.

\section{Materials AND Methods}

This research has been carried out at the Final Waste Disposal Site in Puuwatu Village, Puuwatu District, Kendari City. The choice of location is based on the consideration that the TPAS is one of the final landfill centers and the number of waste collectors is increasing to live or live around the TPAS.

This study uses qualitative descriptive approach research. Where qualitative research methods are research procedures that produce descriptive data in the form of written and oral words from people as well as from observed behavior, according to Bodgam and Taylor (Moleong, 2007). With the aim of qualitative data, this study seeks to look deeper into what is happening in the world and to do everything based on what has been obtained. Because this research is determined by purposive sampling, which means that purposive sampling is a data source collection technique with certain considerations (Sugiyono, 2014). With the requirements of actually being involved in the TPAS environment or living in the place so that researchers took as many as 13 people, including 1 person from the local government, 1 person from the City Sanitation Office, and 11 scavengers who met the qualifications of the resource persons.

The type of data used in this research is qualitative and quantitative data. Qualitative data is data stated in statement or sentence form. The qualitative data needed is a strategy to fulfill the life needs of scavenger families. Quantitative data is data expressed in numbers. The data sources in this study, namely primary data and secondary data. Where the Primary data is directly obtained data from the informant. The data obtained from the informants is a group of scavengers in the final disposal site in the Puuwatu area. Whereas Secondary Data Sources, namely explaining several interpretations that support the primary data and data sources used namely, books, journals, and the internet.

Data collection techniques in this study were divided into four parts, namely:

1. A literature study is an activity to explore and study the theories contained in the library. Literature study activities guide the foresight, perseverance, and accuracy of researchers. In the library activities a researcher will do: (a) Dig deeper into some information and several theories related to the problem being studied, (b) Look for methods and data collection techniques, data analysis techniques and so on, (c) Obtain a view that more broadly about the problem being studied, (d) Avoiding unwanted duplication.

2. Interview or direct and in-depth interviews using the instrument guide, which contains a list of open-ended questions that are used to be used as interviews to be more directed in obtaining more accurate information from informants.

3. There are several forms of observation according to (Bungin, 2007) namely participation observation, unstructured observation, and unstructured group observation. Then, the researcher takes 
participatory observation where the researcher is involved in the informants' daily lives.

4. This is done as a support of the author's research in the form of taking pictures at the study site. Related to the strategy of fulfilling the needs of the scavengers' family life in TPAS.

The data analysis technique is a step that is used to answer the problem formulation in research. According to Ian Dey (Moleong, 2006) said that the core of the analysis lies in three related processes, namely defining phenomena, classifying and seeing how the concepts that emerge are related to one another, so that they can be clearly explained to obtain an understanding and clear facts about the problem in research. Then in determining data analysis, researchers used a qualitative descriptive analysis, which provides a description of the reality or facts that can be used as a basis for determining conclusions, providing suggestions and opinions from the author.

\section{RESUlTS AND DISCUSSION}

\section{Scavenger Constraints In Meeting Family} Life Needs

Scavengers in living their lives are filled with many obstacles, economic, social, and educational obstacles to the way of meeting the needs of life. Life needs that continue to grow and to fulfill it require a lot of money, making scavenger families unable to choose it. Mediocre income makes scavengers must be very economical to meet the needs of living.

Discussing about the constraints of the necessities of life Ali and Salim (in Supriatna, 2000) describe the characteristics of poverty, Ali and Salim's opinion possesses relevance to the constraints faced by scavenger families because Ali and Salim discuss poverty and poverty identical to scavenger families. In dealing with daily life that is not fulfilled, due to the existence of obstacles, namely:

a. Does Not Have Its Production Asset

The poor in general do not have their production assets, even if they have a limited amount so that anywhere to get income is very limited. Scavengers generally do not have their land, but they use the vacant land for them to build a place to live and then they live, if at any time the landowners no longer allow them to stay, they must move to another place. Scavengers can be said to be a group of people whose dwellings are not settled because, on average, they do not have a certain land and house. The scavengers in Puuwatu Village also have the same status, that is, on average, none of them have a certain land and house.

Now the scavengers, who are in Puuwatu SubDistrict, have a house built by the Kendari City Government, but the house is not to be owned but the house is only to be lived in and at any time the City Government can take it. The dirty and chaotic scavenger houses turn neat again when there is free housing ready built by the government of Kendari City, this housing was built to provide decent housing for the poor, the housing was obtained free of charge by meeting the specified conditions by the Kendari City government.

\section{b. Difficult to Get Credit}

For scavengers, obtaining credit for bank loans or financing is very difficult because many requirements must be met, where one of the requirements for obtaining a loan is to have a permanent home and have a clear job. If that is not available then the bank and the financing are very difficult to process. scavenger to get credit at the bank is very difficult to obtain because it is constrained by the requirements and the file, whereas when viewed from the purpose of the KUR funds issued by the government is to help alleviate the burden of small communities by lending KUR funds, but what happens is still small communities such as a scavenger cannot obtain the KUR fund loan.

\section{c. Lack of Alternative Livelihoods}

Scavengers in their work never know tired, activities from morning to evening, work in the garbage dump looking for plastic objects or other objects that can be used or can be sold to make money. All that was done solely to make ends meet. Scavengers in their work only a few of them who have other livelihoods, on average they only work as scavengers. The scavengers in the Puuwatu subdistrict work on average at the final landfill (TPAS) they work from morning to evening, some of them have side jobs, but working as a scavenger is the main occupation. Scavengers in Puuwatu Village who work as scavengers only the rest work alone as scavengers without any other side job. 


\section{Strategy for Fulfilling Family Life Needs of Scavengers}

The term strategy has become a term that is often used by people to describe various meanings such as a plan, tactics, or ways to achieve what is desired. The strategy is essentially planning and management to achieve a goal. However, to achieve this goal, the strategy does not function as a road map that only shows direction, but must be able to show how operational tactics (Chandra 2002). Whereas Quinn (Abdurrahman, 2015) defines strategy as a form or plan that integrates the main objectives, policies, and series of actions in an organization into a unified whole.

Strategy to fulfill family needs according to Fatimah (2016), is an action taken by everyone to be able to maintain their survival and family life through the work they do. The survival strategy was formulated by Snel and Staring as a series of actions chosen consciously by individuals and households that are socially economically poor (Pamungkas and Hidayah, 2013).

In everyday situations, scavengers often get discrimination in social life. Many of the assumptions that scavenging is abusive and inappropriate or some cases are often considered a nuisance to security and comfort. Negative views are often made by the community that scavenger families are usually delinquent and rude, but the community's stigma is accepted by them with a sincere heart to meet the needs of family life.

Financially, the living conditions of scavengers as informal actors can be said to still not be able to meet their daily needs. This is evident from the income they earn per day or per week is only sufficient for basic needs. By him, scavengers in meeting their daily needs, do a variety of ways to survive.

Edi Suharto stated that a survival strategy in dealing with shocks and economic pressures can be done in various ways (Siregar, 2009). To continue living in the future, the community has several things to do to survive, namely:

a. Active Strategy

An active strategy is a survival strategy that is carried out by utilizing all of its potentials. According to Suharto (2009), an active strategy is a strategy carried out by poor families by optimizing all the potentials of the family, for example, doing their activities, extending work hours, and doing anything to increase their income.

For scavenger families who work at the Final Waste Disposal Site (TPAS) in Puuwatu SubDistrict, Puuwatu District, Kendari City, in fulfilling their daily needs, they use what they can when scavenging, for example, broken pots that have been discarded by their owners, these items are scavengers repairing and when the saucepans leak, they patch up, and when the pots are fixed, they repair. Scavengers in fulfilling their daily needs use used goods to survive, such as repairing used items such as pans and then used to cook their daily needs. The other most interesting thing is using plastic to patch a leaky pot, this is the simple knowledge that can be learned and done by others so that the leaky pot can be patched using a simple method.

Scavenging is hard work and is considered humiliating for some people because scavenger work is collecting plastics and used goods at the garbage disposal site is a noble job because, besides halal, scavengers can also help the community in reducing waste and picking up trash that cannot be broken down by bacteria. Besides, by scavenging also many used items that are obtained free of charge and can still be used for daily needs, such as clothes that are discarded by their owners. In the garbage disposal location, many items can still be used such as clothes, pants, and used gloves that have been thrown away by the owner. The scavengers take it and wash it clean and then use it for daily clothing.

\section{b. Passive Strategy}

The passive strategy is a survival strategy that is done by minimizing family expenses, as expressed by Suharto (2009) which states that the passive strategy is a survival strategy by reducing family expenses (for example costs for clothing, food, education, etc.).

Furthermore, according to Kusnadi (2000) a strategy where individuals try to minimize the expenditure of money, this strategy is one of the ways for the poor to survive. This opinion when associated with scavenger families has relevance, where for the family of scavengers in meeting their daily needs they always save money and minimize expenses, for example, to eat and drink, they only eat twice a day, that is eating in the morning before 
scavenging and eat at night when returning from scavenging.

Family scavengers in fulfilling the necessities of life such as food are not solely dependent on rice but tubers are also used as a staple food as a substitute for rice, such as cassava, sweet potatoes, and taro. For vegetables, they prefer to grow their own rather than having to shop at the market, such as growing vegetables, spinach, and so forth.

Scavengers in Puuwatu Village need not only depend on rice, but corn and tubers are an alternative food instead of rice, because for them corn and tubers are cheaper than rice, and tubers can also make stomach becomes full. The scavengers plant tubers around the house, when the tubers are ready to harvest they use it for daily food needs and it can also save their expenses again. For vegetables, the scavengers do not buy anymore at the market because the vegetable needs are already around their homes.

The income of scavengers in working every day is not much; this causes them to be economical to survive because to meet the needs of the family requires a lot of money. Life is very economical for scavenger families is a common thing because since childhood they have been accustomed to living a simple life, to eat only rice alone they are accustomed to not even eating even in a day they are used to. When seen in terms of needs, scavengers also have similar needs with families in general, food, drinking, clothing, housing, and so forth. Scavengers also hope to get all these needs, but because of limited income, they must force themselves to be economical and not buy excessive things, for those who are important to be able to eat, have clothes and a simple house for them is more than enough. Scavengers in the Puuwatu village, for their clothing needs, on average they use clothing obtained at the garbage disposal location, for clothing, very few of them buy it in the market, because the clothes they wear every day are clothes taken at landfills. They also receive gifts from people who feel sorry for their lives.

\section{c. Network Strategy}

Network strategy is a strategy carried out by utilizing social networks. According to Kusnadi (2000), network strategies occur due to social interactions that occur within the community, social networks can help poor families when they need money urgently. This opinion can be understood that the network strategy is a strategy to meet the needs of life that are done by asking for help from relatives, neighbors and other relations both formally and informally when in trouble, such as borrowing money when in urgent need of money. There are many problems faced by scavenger families, they cannot solve it by themselves but need someone else. The scavenger families in the Puuwatu Village also have many obstacles, especially in terms of finance, not a few of them have debt because there is a sudden need to force them to owe. Fellow scavengers also help each other if there are problems faced by other scavenger families. They realize that fellow scavengers must help each other because they expect help from other families according to them is very small. Providing understanding that social relations are very important because there is no doubt that fellow human beings need each other. Social relationships that are built without looking at social stratification and groups, because everything is the same, one human need the other.

\section{ConClusion}

Based on the results of research conducted, it can be concluded that various obstacles faced by scavengers in fulfilling the needs of family life in the Final Waste Disposal Site (TPAS) in Puuwatu Village, Puuwatu Sub district, Kendari City, namely scavengers do not have their production assets, it is difficult to get credit following eye patterns livelihoods, and lack of alternative livelihoods. To survive, scavengers do three strategies, namely active strategy, passive strategy, and network strategy.

Therefore, for scavenger families the need to make efforts to reduce the level of expenditure in shopping for daily life needs, and is also expected to be able to find additional work besides scavenging. While the government is expected to provide financial assistance and training on entrepreneurship so that scavengers can have the skills to find additional family life needs.

\section{REFERENCES}

Abdurrahman, Nana, Herdiana. (2015). Manajemen Strategi Pemasaran. Bandung: Pustaka Setia.

Abidin, Zainal. (2007). Analisis Ekstensial. Jakarta: PT. Grafindo Persada. 
Bungin, B. (2007). Penelitian Kualitatif. Jakarta: Prenada Media Group.

Chandra, G. (2002). Strategi dan Program Pemasaran. Yogyakarta: Andi Offset.

Fatimah, T. (2016). Profil Ekonomi Rumah Tangga Supir Angkutan Antar Kota Pekanbaru Bangkinang. JOM FISIP Vol. 3 No.1.

Gunawan. (2012). Strategi Survival of Life Pemulung. Studi di Tempat Pembuangan Akhir Sampah Ganet Tanjungpinang. Naskah Publikasi Program Studi Sosiologi Fakultas Ilmu Sosial dan Politik Universitas Maritim Raja Ali Haji Tanjungpinang.

Kusnadi. (2000). Nelayan Adaptasi dan Jaringan Sosial. Bandung: Humaniora Utama Press.

Moleong, L. J. (2006). Metodologi Penelitian Kualitatif. Bandung: PT Remaja Rosda Karya.

Pamungkas, Wisnu D. dan Hidayah, N. (2013). Strategi Bertahan Hidup Penjual Makanan Tradisional Serabi di Pasar Turi, Sidomulyo, Bambanglipuro, Bantul, Yogyakarta.

Siregar, Iwan E. (2009). Strategi Adaptasi Petani Rakyat dalam Mensiasati Fluktuasi Harga Kelapa Sawit. Studi Kasus: Petani Kelapa Sawit Rakyat di Desa Tanjung Medan Kecamatan Kampung Rakyat Kabupaten Labuhan Batu Selatan Sumatera Utara. Universitas Sumatera Utara.

Suharto, E. (2009). Membangun Masyarakat Memberdayakan Masyarakat. Bandung: PT Refika Aditama.

Sugiyono. (2014). Metode Penelitian Kuantitatif, Kualitatif dan $R \& D$. Bandung: Alfabeta.

Supriatna T. (2000). Strategi Pembangunan dan Kemiskinan. Jakarta: Rineka Cipta.

Twikromo, Y. A. (1999). Gelandangan Yogyakarta: Suatu Kehidupan dalam Bingkai Tatanan Sosial-Budaya "Resmi". Yogyakarta: Universitas Atmajaya Yogyakarta.

Wurdjinem. (2001). Interaksi Sosial dan Strategi Survival Para Pekerja Sektor Informal. Jurnal Penelitian UNIB Bengkulu Vol.VII No.3. 